\title{
Pengujian Rekomendasi Pemupukan Spesifik Lokasi dan Sistem Tanam terhadap Hasil Padi Sawah di Desa Temega, Kecamatan Abang, Karangasem
}

\section{NYOMAN PUJA*), I WAYAN DANA ATMAJA, DAN MADE SRI SUMARNIASIH}

\author{
J1. PB. Sudirman, Denpasar 80231 Bali \\ ${ }^{*}$ E-mail: pujatenganan@yahoo.com
}

Program Studi Agroekoteknologi Fakultas Pertanian Universitas Udayana

\begin{abstract}
Evaluation of Specific Location Fertilizer Recommendations and Plant System on Rice Yield Temega Village, Abang District, Karangasem. This study aims to determine the response of specific location fertilizer recommendations and planting system on rice yields in Temega Village, Abang District, Karangasem Regency. The method was used Factorial Randomized Block Design (RBD). The treatment tried consisted of two factors. The first factor was fertilization recommendations $(\mathrm{R}): \mathrm{R}_{1}=$ location specific recommendation (250 kg Urea/ha, $100 \mathrm{SP} 36 / \mathrm{ha}$ and $50 \mathrm{~kg} \mathrm{KCl} / \mathrm{ha}) ; \mathrm{R}_{2}=$ Location specific recommendation + Compost (230 kg Urea/ha, $100 \mathrm{SP} 36 / \mathrm{ha}, 50 \mathrm{~kg} \mathrm{KCl} / \mathrm{ha}+5 \mathrm{t}$ compost/ha), $\mathrm{R}_{3}=$ Farmer method (300 kg Urea/ha, $125 \mathrm{SP} 36 / \mathrm{ha}$ and $\left.75 \mathrm{~kg} \mathrm{KCl} / \mathrm{ha}\right)$. The second factor was planting system $(\mathrm{TL}): \mathrm{T}=$ Tegel $(20 \mathrm{~cm} \times 20 \mathrm{~cm})$ and $\mathrm{L}=$ Jajar Legowo $2: 1$. Combination of treatments into 6 treatments and each treatment was replicated 4 times so that there were 24 plots of research. The results showed that location specific fertilizer recommendations resulted in oven dry grain weight $\mathrm{m}^{-2}$ of $0.84 \mathrm{~kg}$ compare to that of farmers $(0.85 \mathrm{~kg})$. The application of location specific fertilizer recommendations can save as much as $50 \mathrm{~kg}$ Urea/ha, $25 \mathrm{~kg} \mathrm{SP} 36 / \mathrm{ha}$ and $25 \mathrm{~kg} \mathrm{KCl} / \mathrm{ha}$. Jajar Legowo planting system can produce grain contain $\mathrm{m}^{-2}$ of $1.14 \mathrm{~kg}$ or an increase of $78.13 \%$ compared to tegel planting system $(0.64 \mathrm{~kg})$.
\end{abstract}

Keywords: rice, fertilizer, location spesific, planting system

\section{PENDAHULUAN}

Pertumbuhan jumlah penduduk terus bertambah sehingga kebutuhan akan pangan meningkat, oleh karena itu sektor pertanian menghadapi tantangan untuk meningkatkan ketersediaan pangan salah satunya beras. Usaha peningkatan produktivitas padi terus dikembangkan sejak tahun 1980 melalui panca usaha tani, sehingga pada tahun 1984 Indonesia mencapai swasembada beras. Setelah swasembada beras tercapai, laju peningkatan produksi padi nasional rata-rata hanya $2 \%$ per tahun, lebih rendah dibandingkan dengan periode sebelum tahun 
I NYOMAN PUJA. et al. Pengujian Rekomendasi Pemupukan Spesifik Lokasi dan Sistem...

1984 yang mencapai 5,2\% per tahun (Makarim, 2005). Penurunan laju produksi ini mengindikasikan telah terjadi pelandaian produksi (levelling off) terutama di lahan sawah beririgasi yang dikelola secara intensif dengan pemberian pupuk anorganik secara terus menerus dengan takaran yang semakin meningkat. Las et al. (2006; dalam Jabri, 2015) menyatakan penggunaan pupuk N,P dan $\mathrm{K}$ secara terus-menerus dengan takaran yang tinggi pada tanah sawah akan mempercepat ketidak seimbangan unsur hara dalam tanah sehingga status kesuburan tanah menjadi merosot. Strategi menghindari ketidak seimbangan unsur hara dalam tanah dapat dilakukan dengan mengacu pemupukan berimbang berdasarkan analisis hara tanah. Petani belum sepenuhnya memahami konsep dan rekomendasi pemupukan berimbang, sehingga pemberian pupuk anorganik lebih tinggi atau lebih rendah dari dosis yang dianjurkan (Wasito et al. 2010; dalam Suyamto dan Saeri, 2018). Hasil wawancara di lapangan dengan 5 orang petani rata-rata menggunakan $300 \mathrm{~kg}$ NPK Ponska/ha dan $200 \mathrm{~kg}$ Urea/ha dengan hasil padi varietas Inpari 30 rata-rata dicapai berkisar 6,0 - 7,0 t/ha. Petani belum mengetahui status kesuburan tanahnya, namun berdasarkan hasil penelitian Puja dan Atmaja (2017) didapatkan status kesuburan tanah sawah berkisar rendah sampai sedang. Artinya pemupukan dengan pupuk anorganik masih perlu dilakukan pada tanah sawah, karena menurut Fairhurts et al. (2007) unsur hara $\mathrm{N}, \mathrm{P}$ dan $\mathrm{K}$ yang terangkut dalam tanaman padi melalui setiap ton gabah dan jerami berturut-turut $15-17,5 \mathrm{~kg} \mathrm{~N}, 2,6-3 \mathrm{~kg} \mathrm{P}$ dan 15 - $17 \mathrm{~kg} \mathrm{~K}$. Sejalan dengan pendapat Kasniari dan Supadma (2007) menyatakan teknologi pemupukan merupakan salah satu faktor penentu di dalam upaya meningkatkan produksi pangan.

Upaya peningkatan produktivitas padi dapat dilakukan dengan sistem tanam Jajar Legowo yang merupakan teknik mengatur jarak tanam antar rumpun dan antar barisan, sehingga jumlah populasi rumpun dalam barisan meningkat dan jarak antar barisan tanaman menjadi lebih lebar, memberikan kondisi lebih baik pada setiap tanaman pinggir (Ezwar et al., 2017). Tanaman pinggir secara umum menunjukkan hasil lebih tinggi daripada tanaman yang ada di bagian dalam barisan, karena persaingan tanaman antar barisan dapat dikurangi terutama terhadap sinar matahari sehingga dapat dimanfaatkan lebih banyak untuk proses fotosintesis (Anggraini et al., 2013).

Produktivitas tanah sawah sangat ditentukan oleh kualitas tanah, yang dicerminkan dari status kesuburan tanahnya. 
Status kesuburan tanah sawah di Kecamatan Abang, Kabupaten Karangasem Provinsi Bali berdasarkan hasil penelitian Puja dan Atmaja (2017) memiliki status kesuburan tanah rendah sampai sedang. Rekomendasi pemupukan berdasarkan status kesuburan tanah didapatkan pada daerah yang berstatus kesuburan tanah rendah sebanyak $250 \mathrm{~kg}$ Urea/ha, $100 \mathrm{SP} 36 / \mathrm{ha}$ dan $50 \mathrm{~kg} \mathrm{KCl/ha.}$ Kompos jerami padi jika dikembalikan kedalam tanah sebanyak 5 ton/ha, maka rekomendasi pemupukan menjadi $230 \mathrm{~kg}$ Urea/ha, $100 \mathrm{~kg}$ SP36 dan $50 \mathrm{~kg} \mathrm{KCl}$. Daerah yang berstatus kesuburan tanah sedang, rekomendasi pemupukan sebanyak $250 \mathrm{~kg}$ Urea/ha, $75 \mathrm{SP} 36 / \mathrm{ha}$ dan $50 \mathrm{~kg}$ $\mathrm{KCl} / \mathrm{ha}$. Kompos jerami padi jika dikembalikan kedalam tanah sebanyak 5 ton/ha maka rekomendasi pemupukan menjadi $230 \mathrm{~kg}$ Urea/ha $75 \mathrm{~kg}$ SP36 dan 0 $\mathrm{kg} \mathrm{KCl}$.

Berdasarkan hasil penelitian sebelumnya oleh Puja dan Atmaja (2017) maka perlu hasil rekomendasi pemupukan tersebut diuji langsung di lapangan dengan tujuan untuk mengetahui respon rekomendasi pemupukan spesifik lokasi dan sistem tanam terhadap hasil padi sawah. Hasil penelitian ini diharapkan menjadi pedoman dalam penerapan dosis pupuk spesifik lokasi pada tanaman padi sawah yang lebih efisien.

\section{BAHAN DAN METODE}

Penelitian dilaksanakan pada lahan sawah yang memiliki status kesuburan tanah rendah di Desa Temega, Kecamatan Abang, Karangasem mulai bulan Mei - September 2018. Bahan yang digunakan dalam penelitian ini adalah benih padi varietas Inpari 30, kompos dari limbah ternak sapi, pupuk Urea, SP36, KCl. Alat yang digunakan traktor, cangkul, meteran, timbangan, oven dan alat tulis. Metode penelitian menggunakan Rancangan Acak Kelompok (RAK) terdiri atas dua faktor yaitu :

1. Rekomendasi pemupukan (R) terdiri atas 3 taraf yaitu :

R1 = Spesifik Lokasi (250 kg Urea/ha, 100 SP36/ha dan $50 \mathrm{~kg} \mathrm{KCl} / \mathrm{ha}$ )

$\mathrm{R} 2$ = Spesifik Lokasi + Kompos (230 kg Urea/ha, $100 \mathrm{~kg} \mathrm{SP} 36 / \mathrm{ha}, 50 \mathrm{~kg} \mathrm{KCl} / \mathrm{ha}+5$ ton kompos/ha)

R3 = Cara Petani $(300 \mathrm{~kg}$ Ponska/ha $+200 \mathrm{~kg}$ Urea/ha atau setara $300 \mathrm{~kg}$ Urea/ha +125 $\mathrm{kg} \mathrm{SP} 36 / \mathrm{ha}+75 \mathrm{~kg} \mathrm{KCl} / \mathrm{ha})$ 
I NYOMAN PUJA. et al. Pengujian Rekomendasi Pemupukan Spesifik Lokasi dan Sistem...

2. Sistem Tanam (ST) terdiri atas 2 taraf penambahan yaitu :

$\mathrm{T}=$ Tegel $(20 \mathrm{~cm} \times 20 \mathrm{~cm})$

$\mathrm{L}=$ Jajar Legowo 2: 1 (10 cm antar tanaman dalam barisan x $20 \mathrm{~cm}$ antar barisan tanaman x 40 antar legowo).

Kombinasi perlakuan menjadi 6 yaitu :R1L,R1T, R2L, R2T, R3L, dan R3T, dan masing-masing perlakuan diulang sebanyak 4 kali sehingga terdapat 24 perlakuan. (24 petak penelitian). Tahapan penelitian sebagai berikut : Tanah diolah dengan menggunakan bajak singkal sebanyak satu kali, kemudian dilanjutkan dengan bajak rotari satu kali. Penggaruan dilakukan berselang 3 hari dari waktu pembajakan dengan tujuan untuk membuat tanah menjadi lumpur dan rata, sehingga memudahkan penanaman bibit padi.

Pemupukan dilakukan pada setiap petak penelitian dengan dosis sesuai perlakuan yaitu $\mathrm{R}_{1}=$ Rekomendasi Spesifik Lokasi (250 kg Urea/ha + $100 \mathrm{~kg} \mathrm{SP36} \mathrm{+} 50$ $\mathrm{kg} \mathrm{KCl} / \mathrm{ha}), \mathrm{R}_{2}=$ Rekomendasi Spesifik Lokasi + Kompos (230 kg Urea/ha + $100 \mathrm{~kg}$ SP-36/ha $+50 \mathrm{~kg} \mathrm{KCl} / \mathrm{ha}+5$ ton kompos/ha) dan $\mathrm{R}_{3}=$ Cara petani $(300 \mathrm{~kg}$ Urea $+125 \mathrm{~kg}$ SP-36 + 75 kg KCl). Pupuk SP36, $\mathrm{KCl}$ dan kompos diberikan seluruhnya sehari sebelum tanam. Pupuk Urea diberikan sebanyak 3 kali yaitu $25 \%$ dosis diberikan pada umur tanaman 1 minggu setelah tanam (mst), $50 \%$ pada umur tanaman 4 mst dan $25 \%$ pada umur tanaman 8 mst.

Penanaman dilakukan dengan sistem tanam pindah, artinya setelah bibit padi varietas Inpari 30 berumur 21 hari, selanjutnya dipindahkan ke petak penelitian sesuai perlakuannya. Perlakuan sistem Tegel ditanam dengan jarak tanam $20 \mathrm{~cm}$ x $20 \mathrm{~cm}$ dan perlakuan sistem Jajar Legowo 2 : 1, bibit ditanam dengan jarak $10 \mathrm{~cm}$ antar tanaman dalam barisan x $20 \mathrm{~cm}$ antar baris tanaman x $40 \mathrm{~cm}$ antar Jajar Legowo.

Pengendalian organisme pengganggu tanaman (OPT) terhadap gulma dengan cara manual (penyiangan). Pengendalian hama dan penyakit tanaman tidak dilakukan karena selama penelitian tidak menunjukkan adanya gejala serangan hama dan penyakit.

\section{Pengamatan}

Parameter tanaman yang dimati adalah: 1) Tinggi tanaman diukur dari permukaan tanah sampai ujung tanaman tertinggi. 2) Jumlah anakan per $\mathrm{m}^{2}$ diamati dengan menghitung semua tanaman seluas $1 \mathrm{~m}^{2} .3$ ) Berat jerami per $\mathrm{m}^{2}$ diamati setelah panen 
dengan menimbang berat jerami setelah dikeringkan dalam oven sampai kering mutlak seluas $1 \mathrm{~m}^{2}$. 4) Berat gabah berisi kering per $\mathrm{m}^{2}$ diamati setelah panen dengan cara menimbang berat gabah berisi setelah dikeringkan dalam oven sampai kering mutlak seluas $1 \mathrm{~m}^{2}$ dan 5) Berat gabah hampa per $\mathrm{m}^{2}$ diamati setelah panen dengan cara menimbang berat gabah hampa setelah dikeringkan dalam oven sampai kering mutlak $\left(70-80^{\circ} \mathrm{C}\right)$ seluas $1 \mathrm{~m}^{2}$.

\section{Analisis Data}

Data hasil pengamatan parameter tanaman dianalisis secara statistika sesuai dengan rancangan yang digunakan, jika perlakuan menunjukkan pengaruh yang nyata atau sangat nyata maka dilanjutkan dengan uji Beda Nilai Terkecil (BNT) pada tingkat kepercayaan $5 \%$.

\section{HASIL DAN PEMBAHASAN}

Hasil analisis statistika menunjukkan perlakuan rekomendasi pemupukan spesifik nyata terhadap hampir semua parameter tanaman yang diamati, kecuali perlakuan sistem tanam secara tunggal berpengaruh sangat nyata terhadap jumlah anakan per $\mathrm{m}^{2}$, berat jerami kering per $\mathrm{m}^{2}$ dan berat gabah berisi kering oven per $\mathrm{m}^{2}$. Secara lebih rinci pengaruh pengujian rekomendasi pemupukan spesifik lokasi dan sistem tanam terhadap parameter yang diamati disajikan pada Tabel 1.

Tabel 1. Pengaruh Pengujian Rekomendasi Pemupukan dan Sistem Tanam terhadap Parameter Tanaman Padi

\begin{tabular}{|c|c|c|c|c|c|}
\hline \multirow[t]{2}{*}{ Perlakuan } & \multicolumn{5}{|c|}{ Parameter Tanaman } \\
\hline & $\begin{array}{l}\text { Tinggi Tanaman } \\
(\mathrm{cm})\end{array}$ & $\begin{array}{l}\text { Jumlah Anakan } \\
\text { per } \mathrm{m}^{2}(\mathrm{bt})\end{array}$ & $\begin{array}{l}\text { Berat Jerami Kering } \\
\text { Oven per } \mathrm{m}^{2}(\mathrm{~kg})\end{array}$ & $\begin{array}{c}\text { Berat Gabah } \\
\text { Berisi per } \mathrm{m}^{2} \\
(\mathrm{~kg})\end{array}$ & $\begin{array}{c}\text { Berat Gabah } \\
\text { Hampa per } \mathrm{m}^{2} \\
(\mathrm{~kg})\end{array}$ \\
\hline \multicolumn{6}{|c|}{ Rekomendasi (R) } \\
\hline $\mathrm{R} 1$ & 88,88 a & $428.75 \mathrm{a}$ & $1.06 \mathrm{a}$ & $0.84 \mathrm{a}$ & $0.19 \mathrm{a}$ \\
\hline R2 & $88,50 \mathrm{a}$ & $440.63 \mathrm{a}$ & $1.11 \mathrm{a}$ & $0.99 \mathrm{a}$ & $0.18 \mathrm{a}$ \\
\hline R3 & $93,00 \mathrm{a}$ & $468.75 \mathrm{a}$ & $1.12 \mathrm{a}$ & $0.85 \mathrm{a}$ & $0.19 \mathrm{a}$ \\
\hline BNT $5 \%$ & 4,19 & 123,01 & $\mathbf{0 , 1 7}$ & 0,12 & 0,05 \\
\hline \multicolumn{6}{|c|}{ SistemTanam (ST) } \\
\hline $\mathrm{L}$ & $90,42 \mathrm{a}$ & $556,67 \mathrm{~b}$ & $1.38 \mathrm{~b}$ & $1.14 \mathrm{~b}$ & $0,18 \mathrm{a}$ \\
\hline $\mathrm{T}$ & 89,83 a & $335.42 \mathrm{a}$ & $0,81 \mathrm{a}$ & $0,64 \mathrm{a}$ & $0,19 \mathrm{a}$ \\
\hline BNT $5 \%$ & 3,42 & 100,44 & 0,14 & 0,10 & 0,04 \\
\hline \multicolumn{6}{|c|}{ Interaksi R x ST } \\
\hline $\mathrm{R} 1 \mathrm{~L}$ & $94,50 \mathrm{a}$ & $520.00 \mathrm{a}$ & $1.28 \mathrm{a}$ & $1.05 \mathrm{a}$ & $0.18 \mathrm{a}$ \\
\hline $\mathrm{R} 1 \mathrm{~T}$ & $91,50 \mathrm{a}$ & $337.50 \mathrm{a}$ & $0.84 \mathrm{a}$ & $0.63 \mathrm{a}$ & $0.20 \mathrm{a}$ \\
\hline R2L & 88,25 a & $550.00 \mathrm{a}$ & $1.45 \mathrm{a}$ & $1.33 \mathrm{a}$ & $0.18 \mathrm{a}$ \\
\hline $\mathrm{R} 2 \mathrm{~T}$ & $88,75 \mathrm{a}$ & $331.25 \mathrm{a}$ & $0.77 \mathrm{a}$ & $0.65 \mathrm{a}$ & $0.17 \mathrm{a}$ \\
\hline R3L & $88,50 \mathrm{a}$ & $600.00 \mathrm{a}$ & $1.39 \mathrm{a}$ & $1.05 \mathrm{a}$ & $0.18 \mathrm{a}$ \\
\hline R3T & $89,25 \mathrm{a}$ & $337.50 \mathrm{a}$ & $0.84 \mathrm{a}$ & $0.65 \mathrm{a}$ & $0.21 \mathrm{a}$ \\
\hline BNT $5 \%$ & 5,92 & 181.88 & 0,24 & $\mathbf{0 , 1 7}$ & $\mathbf{0 , 0 7}$ \\
\hline
\end{tabular}

Keterangan: Angka-Angka yang diikuti oleh huruf yang sama pada kolom yang sama menunjukkan berbeda tidak nyata pada uji BNT taraf $5 \%$ 
I NYOMAN PUJA. et al. Pengujian Rekomendasi Pemupukan Spesifik Lokasi dan Sistem...

\section{Tinggi Tanaman}

Perlakuan rekomendasi pemupukan spesifik lokasi memberikan pengaruh yang tidak nyata terhadap tinggi tanaman padi disebabkan pemupukan berdasarkan rekomendasi spesifik lokasi telah mampu memenuhi kebutuhan unsur hara untuk pertumbuhan tinggi tanaman padi. Hal ini dapat terlihat dari hasil pengamatan tinggi tanaman menunjukkan perlakuan rekomendasi pemupukan spesifik lokasi menghasilkan tinggi tanaman $88,88 \mathrm{~cm}$ berbeda tidak nyata dengan cara petani $(93,00 \mathrm{~cm})$. Ini berarti pemupukan spesifik lokasi dengan dosis yang lebih rendah dibandingkan dengan cara petani tidak secara nyata dapat menurunkan tinggi tanaman, namun dapat mengefisienkan penggunaan pupuk sebanyak $50 \mathrm{~kg}$ Urea/ha, $25 \mathrm{~kg}$ SP36/ha dan $25 \mathrm{~kg}$. KCl/ha. Dosis pupuk pada tanaman padi yang dilakukan oleh petani berdasarkan acuan RDKK (Rencana Definitif Kebutuhan Kelompok) yaitu $300 \mathrm{~kg}$ Ponska/ha dan $200 \mathrm{~kg}$ Urea/ha atau setara dengan $300 \mathrm{~kg}$ Urea/ha, $125 \mathrm{~kg}$ SP36 dan 75 $\mathrm{kg} \mathrm{KCl} / \mathrm{ha}$. Hasil penelitian ini sesuai dengan hasil penelitian Samijan et al., (2017) menyatakan pemupukan berdasarkan hara spesifik lokasi (PHSL) menghasilkan tinggi tanaman yang berbeda tidak nyata dibandingkan dengan cara petani.
Perlakuan sistem tanam memberikan pengaruh yang tidak nyata terhadap tinggi tanaman disebabkan sistem tanam bertujuan mengatur tata letak tanaman padi sedemikian rupa agar populasi tanaman per satuan luas lebih banyak. Hal ini dapat terlihat pada hasil pengamatan pada sistem tanam Jajar Legowo menghasilkan tinggi tanaman 90,42 cm berbeda tidak nyata dengan perlakuan sistem Tegel 89,83 cm. Bobihoe (2013; dalam Ezward et al., dkk. 2017) menyatakan sistem tanam Jajar Legowo bertujuan untuk memperbanyak jumlah rumpun per satuan luas (bukan tinggi tanaman) dengan mengatur tanaman sehingga sebagian tanaman menjadi tanaman pinggir dalam upaya untuk memanfaatkan cahaya matahari. Sistem tanam Jajar Legowo memberikan ruang tumbuh yang lebih luas, sehingga mampu memberikan sirkulasi udara dan pemanfaatan energi matahari yang lebih baik untuk pertumbuhan tanaman.

\section{Jumlah Anakan per $\mathbf{m}^{2}$}

Perlakuan rekomendasi pemupukan dan sistem tanam memberikan pengaruh yang tidak nyata terhadap jumlah anakan per $\mathrm{m}^{2}$ disebabkan pemupukan berdasarkan rekomendasi spesifik lokasi telah mampu memberikan unsur hara yang cukup untuk pertumbuhan anakan per $\mathrm{m}^{2}$. Hasil pengamatan menunjukkan perlakuan 
rekomendasi pemupukan spesifik lokasi Ezwar et al., 2017) menyatakan pada memberikan jumlah anakan per $\mathrm{m}^{2}$ sebanyak prinsipnya sistem tanam Jajar Legowo 428,75 bt berbeda tidak nyata dengan meningkatkan populasi tanaman dengan cara pemupukan spesifik lokasi +5 ton mengatur jarak tanam dan mengatur sebagian kompos/ha (440,63 bt) dan cara petani tanaman menjadi tanaman pinggir untuk (468,75 bt). Ini berarti penerapan pemupukan memberikan ruang tumbuh yang lebih luas, berdasarkan rekomendasi pemupukan sehingga mampu memberikan sirkulasi udara spesifik lokasi dengan dosis yang lebih dan pemanfaatan energi matahari yang lebih rendah dibandingkan dengan cara petani baik untuk pertumbuhan tanaman.

tidak secara nyata menurunkan jumlah anakan tanaman padi, namun dapat menghemat penggunaan pupuk sebanyak 50 $\mathrm{kg}$ Urea/ha, $25 \mathrm{~kg}$ SP36/ha dan $25 \mathrm{~kg}$ $\mathrm{KCl} / \mathrm{ha}$.

Perlakuan sistem tanam memberikan pengaruh yang sangat nyata terhadap jumlah anakan per $\mathrm{m}^{2}$ disebabkan perlakuan sistem tanam bertujuan untuk memodifikasi tata letak tanaman yang biasa dilakukan petani dengan memindahkan satu baris tanaman kedalam barisan tanaman yang lain, sehingga tanaman menjadi lebih rapat dalam setiap barisan dan jumlah tanaman per satuan luas menjadi lebih banyak. Rata-rata jumlah anakan per $\mathrm{m}^{2}$ dapat dilihat pada Tabel 1 , perlakuan sistem tanam Jajar Legowo menghasilkan jumlah anakan sebanyak 556,67 bt per $\mathrm{m}^{2}$ atau meningkatkan sebesar $65,96 \%$ dibandingkan dengan sistem tanam Tegel (335.42 bt per $\mathrm{m}^{2}$ ). Hal ini sesuai dengan pendapat Ikhwani (2013; dalam

\section{Berat Jerami Kering Oven per $\mathbf{m}^{2}$}

Perlakuan rekomendasi pemupukan memberikan pengaruh yang tidak nyata terhadap berat jerami kering oven per $\mathrm{m}^{2}$ disebabkan jumlah anakan per $\mathrm{m}^{2}$ yang dihasilkan dari perlakuan rekomendasi pemupukan menunjukkan perbedaan yang tidak nyata. Jumlah anakan per satuan luas berpengaruh terhadap berat jerami kering per satuan luas yaitu makin banyak jumlah anakan per satuan luas, maka makin berat besar berat jerami kering per satuan luas. Hasil penelitian menunjukkan perlakuan rekomendasi pemupukan spesifik lokasi menghasilkan berat jerami kering oven per $\mathrm{m}^{2}$ sebesar $1,06 \mathrm{~kg}$, berbeda tidak nyata dengan rekomendasi spesifik lokasi +5 ton kompos/ha $(1,11 \mathrm{~kg})$ dan cara petani $1,12 \mathrm{~kg}$. Ini berarti penerapan pemupukan berdasarkan rekomendasi spesifik lokasi dengan mengurangi dosis pupuk sebanyak 50 
I NYOMAN PUJA. et al. Pengujian Rekomendasi Pemupukan Spesifik Lokasi dan Sistem...

$\mathrm{kg}$ Urea/ha, $25 \mathrm{~kg} \mathrm{Sp}-36 / \mathrm{ha}$ dan $25 \mathrm{~kg} \mathrm{~m}^{2}$ disebabkan jumlah anakan per $\mathrm{m}^{2}$ tidak $\mathrm{KCl} /$ ha dapat menghasilkan berat jerami berbeda nyata antara perlakuan, sehingga kering oven tidak berbeda nyata berpengaruh juga terhadap berat gabah berisi dibandingkan dengan cara petani.

Perlakuan sistem tanam memberikan pengaruh yang sangat nyata terhadap berat jerami kering oven per $\mathrm{m}^{2}$ disebabkan sistem tanam bertujuan memperbanyak jumlah populasi tanaman per satuan luas, memaksimalkan penyerapan cahaya matahari yang akan berpengaruh terhadap bahan kering (dry matter) yang dihasilkan. Hal ini dapat terlihat pada perlakuan sistem tanam jajar legowo memberikan berat jerami kering oven per $\mathrm{m}^{2}$ sebesar $1,38 \mathrm{~kg}$ atau meningkat $70,37 \%$ dibandingkan dengan perlakuan sistem tanam Tegel $(0,81 \mathrm{~kg})$. Hasil ini didukung oleh hasil pengamatan jumlah anakan per $\mathrm{m}^{2}$ dimana sistem Jajar Legowo dapat meningkatkan jumlah anakan per satuan luas yang sangat nyata dibandingkan dengan sistem tanam Tegel. Jumlah anakan per satuan luas berhubungan langsung dengan berat kering tanaman yaitu semakin banyak jumlah tanaman per satuan luas semakin besar berat jerami kering tanaman.

\section{Berat Gabah Berisi Kering Oven per $\mathbf{m}^{2}$}

Perlakuan rekomendasi pemupukan memberikan pengaruh yang tidak nyata terhadap berat gabah berisi kering oven per

$\mathrm{m}^{2}$ ditentukan oleh salah satu faktor jumlah anakan per $\mathrm{m}^{2}$ yaitu makin banyak jumlah anakan maka makin banyak menghasilkan jumlah gabah dan makin besar memberikan sumbangan terhadap berat gabah berisi per $\mathrm{m}^{2}$. Hasil penelitian menunjukkan perlakuan rekomendasi spesifik lokasi memberikan berat gabah berisi kering oven per $\mathrm{m}^{2}$ sebesar $0,84 \mathrm{~kg}$, berbeda tidak nyata dengan rekomendasi spesifik lokasi +5 ton kompos/ha $(0,99 \mathrm{~kg})$ dan cara petani $0,85 \mathrm{~kg}$. Ini berarti penerapan pemupukan berdasarkan rekomendasi spesifik lokasi walaupun dengan mengurangi dosis pupuk sebanyak $50 \mathrm{~kg}$ Urea/ha, $25 \mathrm{~kg}$ SP-36/ha dan $25 \mathrm{~kg} \mathrm{KCl} / \mathrm{ha}$ mampu menghasilkan berat gabah berisi kering oven sebanding dengan cara petani.

Perlakuan sistem tanam memberikan pengaruh yang sangat nyata terhadap berat gabah berisi kering oven disebabkan sistem tanam bertujuan mengatur tata letak tanaman memperbanyak jumlah anakan per satuan luas, mengatur sebagian tanaman menjadi tanaman pinggir dan meningkatkan hasil tanaman. Hasil penelitian menunjukkan perlakuan sistem tanam Jajar Legowo 
menghasilkan berat gabah berisi kering oven per $\mathrm{m}^{2}$ sebanyak $1,14 \mathrm{~kg}$ atau meningkat sebesar 78,13\% dibandingkan sistem tanam Tegel yaitu $0,64 \mathrm{~kg}$. Sistem tanam Jajar Legowo memberikan jumlah anakan secara nyata lebih tinggi dibandingkan dengan sistem tanam Tegel dan sebagian tanaman menjadi tanaman pinggir. Tanaman padi yang ada dipinggir akan mendapatkan ruang yang lebih besar untuk memperoleh sinar matahari, sehingga tanaman mampu melakukan proses fotosintesis yang lebih baik dan menghasilkan gabah berisi yang lebih tinggi. Hal ini didukung oleh hasil pengamatan pada sistem tanam Jajar Legowo secara nyata dapat meningkatkan jumlah anakan dan berat jerami kering oven per $\mathrm{m}^{2}$. Jumlah anakan dan berat jerami kering oven berhubungan dengan hasil gabah berisi yaitu semakin tinggi jumlah anakan dan berat jerami kering oven maka semakin besar berat gabah berisi per $\mathrm{m}^{2}$. Hasil penelitian ini sesuai dengan hasil penelitian Rebekka (2018) dan Anggraini et al., dkk. (2013) yaitu sistem tanam Jajar Legowo mampu meningkatkan produksi gabah kering panen sebesar 12,36 \% bila dibandingkan sistem tanam Tegel (5,67 ton/ha).

\section{Berat Gabah Hampa Kering Oven per $\mathbf{m}^{2}$}

Perlakuan rekomendasi spesifik lokasi memberikan pengaruh yang tidak nyata terhadap berat gabah hampa kering oven per m2 disebabkan jumlah anakan tidak menunjukkan perbedaan yang nyata antara perlakuan. Berat gabah hampa per $\mathrm{m} 2$ dipengaruhi oleh salah satu faktor yaitu jumlah anakan, semakin banyak jumlah anakan per satuan luas maka semakin besar berat gabah hampa. Hasil penelitian menunjukkan pemupukan berdasarkan rekomendasi pemupukan spesifik lokasi memberikan berat gabah hampa per $\mathrm{m}^{2}$ sebesar 0,19 $\mathrm{kg}$ berbeda tidak nyata dengan rekomendasi spesifik lokasi +5 ton kompos/ha $(0,18 \mathrm{~kg})$ dan cara petani $(0,19$ $\mathrm{kg}$ ). Ini berarti penerapan pemupukan berdasarkan rekomendasi spesifik lokasi dengan mengurangi dosis pupuk sebanyak 50 $\mathrm{kg} \mathrm{Urea/ha,} 25 \mathrm{~kg} \mathrm{SP} 36 / \mathrm{ha}$ dan $25 \mathrm{~kg} \mathrm{KCl} / \mathrm{ha}$ tidak dapat meningkatkan berat gabah hampa per $\mathrm{m}^{2}$.

Perlakuan sistem tanam memberikan pengaruh yang tidak nyata terhadap berat gabah hampa kering oven per $\mathrm{m}^{2}$ disebabkan sistem tanam merupakan pengaturan tata letak tanaman. Sistem tanam Jajar Legowo bertujuan pengaturan tata letak tanaman, sehingga sebagian besar tanaman menjadi tanaman pinggir. Tanaman pinggir akan 
I NYOMAN PUJA. et al. Pengujian Rekomendasi Pemupukan Spesifik Lokasi dan Sistem...

mendapatkan sinar matahari yang lebih optimal sehingga proses fotosintesa dan pengisian gabah padi berjalan lebih sempurna atau gabah hampa menjadi lebih sedikit. Berdasarkan Tabel 1, Sistem jajar legowo dari segi populasi tanaman lebih tinggi, namun berat gabah hampa kering oven per $\mathrm{m}^{2}$ yang dihasilkan sebanding dengan perlakuan sistem Tegel.

\section{SIMPULAN}

Berdasarkan hasil penelitian pengujian rekomendasi pemupukan terhadap hasil padi sawah dapat disimpulkan bahwa rekomendasi pemupukan spesifik lokasi menghasilkan berat gabah berisi per $\mathrm{m}^{2}$ sebesar 0,84 kg sebanding dengan cara petani $(0,85 \mathrm{~kg})$. Penerapan rekomendasi pemupukan spesifik lokasi mampu menghemat pupuk sebanyak $50 \mathrm{~kg}$ Urea/ha, $25 \mathrm{~kg} \quad \mathrm{SP} 36 / \mathrm{ha}$ dan $25 \mathrm{~kg} \quad \mathrm{KCl} / \mathrm{ha}$ dibandingkan cara petani. Sistem tanam Jajar Legowo menghasilkan berat gabah berisi per $\mathrm{m}^{2}$ sebesar $1,14 \mathrm{~kg}$ atau meningkat 78,13\% dibandingkan sistem tanam Tegel $(0,64 \mathrm{~kg})$.

\section{UCAPAN TERIMA KASIH}

Tim peneliti mengucapkan terima kasih kepada Rektor Universitas Udayana atas dana yang telah diberikan melalui Penelitian Unggulan Program Studi sesuai dengan kontrak penugasan DIPA Universitas Udayana dengan Surat Perintah Kegiatan (SPK) No. 972/UN1 4,2,6/II/LT/2018, tanggal 2 April 2018. Tim juga berterima kasih kepada Dekan Fakultas Pertanian dan semua pihak yang penulis tidak dapat sebutkan namanya satu per satu atas bantuan dan dukungannya terhadap kegiatan ini.

\section{DAFTAR PUSTAKA}

Anggraini F., AgusSuryanto, Nurul Aini. 2013. SistemTanam Dan Umur Bibit Pada Tanaman Padi Sawah (Oryza sativa L.) Varietas Inpari13. Jurnal Produksi Tanaman Vol. 1 (2) : 52 - 60

Ezward Chairil, ElfiIndrawanis, Seprido dan Mashadi. 2017. Peningkatan Produktivitas Tanaman Padi melalui Teknik Budidaya dan Pupuk Kompos Jerami. Jurnal Agrosains dan Teknologi, Vol 2 (1) : $51-67$

Jabri, M-Al. 2013. Teknologi Uji Tanah untuk Penyusunan Rekomendasi Pemupukan Berimbang Tanaman Padi Sawah. Pengembangan Inovasi Pertanian Vol. 6 (1) : $11-22$.

Makarim, A. Karim; Djuber Pasaribu; Zulkipli Zaini dan Irsal Las, 2005. Analisis dan Sintesis Pengembangan Model PengelolaanTanamanTerpadu Padi Sawah, Balai Penelitian Tanaman Padi. Pusat Penelitian dan Pengembangan Tanaman Pangan Badan Penelitian dan Pengembangan Pertanian. Sukamandi.

Puja, I Nyoman dan I Wayan Dana Atmaja. 2017. Penetapan Dosis Pupuk Spesifik Lokasi Untuk Tanaman Padi Sawah Berdasarkan Evaluasi Status Kesuburan Tanah di Kecamatan Abang Karangasem (belum dipublikasikan). 
Rebekka L., Jonatan Ginting dan Haryati. 2018. Pengaruh Sistem Tanam Jajar Legowo Terhadap Pertumbuhan dan Produksi Beberapa Varietas Padi Sawah (Oryza sativa L.). Jurnal Agroekoteknologi FP USU Vol.6 (3) : 576- 581

Rochayati, S, dan J, S, Adiningsih. 1997. Penelitian pengelolaan hara terpadu pada lahan sawah. Laporan Akhir Program Penelitian Status dan Pengelolaan Hara Terpadu pada Lahan Sawah. Puslittanak Bogor.

Kasniari, DN dan A.A.N. Supadma. 2007. Pengaruh pemberian beberapa dosis pupuk $(\mathrm{N}, \mathrm{P}, \mathrm{K})$ dan jenis pupuk alternative terhadap hasil tanaman padi (Oryza sativa L.) dan kadar N, P, K inceptisol Selemadeg, Tabanan. Agrotrop 24 (6) : 168 - 176.

Saeroji. 2013. Sistem Jajar Legowo dapat Meningkatkan Produktivitas Padi. Balai Besar Pelatihan Pertanian. Malang.

Salikin, K.A. 2003. Sistem Pertenian Berkelanjutan. Kanisius. Yogyakarta.

Samijan, Tri Reni Prastuti dan Warsito. 2017. Evaluasi Lapang Rekomendasi Pemupukan Padi Sawah Berdasarkan Pemupukan Spesifik Lokasi Berbasis Internet di Jawa Tengah Indonesia. Jurnal Agrosains (Journal of Agro Science), Vol. 5 (1) : $23-33$

Suyamto dan M, Saeri. 2018. Evaluasi Rekomendasi Pemupukan Hara Spesifik Lokasi pada Padi Sawah di Jawa Timur. Jurnal Penelitian Pertanian Tanaman Pangan Vol 2, No, 1 , hal : $1-8$.

Syahri dan Renny Utami Somantri. 2013. Respon Pertumbuhan Tanaman Padi terhadap Rekomendasi Pemupukan PUTS dan KATAM Hasil Litbang Pertanian di Lahan Rawa Sumatra Selatan. Jurnal Lahan Sub optimal. Vol. 2(2) : $170-180$. 